\title{
The Senate, the Constitution, and the Confirmation Process
}

\section{Citation}

David A. Strauss \& Cass R. Sunstein, The Senate, the Constitution, and the Confirmation Process, 101 Yale L. J. 1491 (1992).

\section{Published Version}

http://chicagounbound.uchicago.edu/journal_articles/2018/

\section{Permanent link}

http://nrs.harvard.edu/urn-3:HUL.InstRepos:12933368

\section{Terms of Use}

This article was downloaded from Harvard University's DASH repository, and is made available under the terms and conditions applicable to Other Posted Material, as set forth at http:// nrs.harvard.edu/urn-3:HUL.InstRepos:dash.current.terms-of-use\#LAA

\section{Share Your Story}

The Harvard community has made this article openly available.

Please share how this access benefits you. Submit a story.

Accessibility 


\section{University of Chicago Law School Chicago Unbound}

Journal Articles

Faculty Scholarship

1992

\section{The Senate, the Constitution, and the Confirmation Process}

David A. Strauss

Cass R. Sunstein

Follow this and additional works at: http://chicagounbound.uchicago.edu/journal_articles Part of the Law Commons

\section{Recommended Citation}

David A. Strauss \& Cass R. Sunstein, "The Senate, the Constitution, and the Confirmation Process," 101 Yale Law Journal 1491 (1992).

This Article is brought to you for free and open access by the Faculty Scholarship at Chicago Unbound. It has been accepted for inclusion in Journal Articles by an authorized administrator of Chicago Unbound. For more information, please contact unbound@law.uchicago.edu. 


\title{
The Senate, the Constitution, and the
}

\section{Confirmation Process}

\author{
David A. Strauss $\grave{\dagger}$ and Cass R. Sunstein $\dagger_{\dagger} \dagger$
}

It is difficult to find anyone who is satisfied with the way Supreme Court Justices are appointed today. Many of the criticisms are prompted by partisanship, of course. But there is a substantial element of truth in the complaints made by partisans on both sides. And those who are not partisan, but who simply want a healthy process that conforms to the constitutional design and is likely to produce the best appointments, have perhaps the most to criticize.

In this Essay, we suggest that a return to the confirmation process contemplated by the text and structure of the Constitution-a process in which the Senate plays a more independent role than it does today-would help eliminate aspects of the system that both sides, Administration supporters as well as Administration critics, find objectionable. It would also produce a better Court along two dimensions: a Court with Justices of greater distinction, and a Court that reflects a more appropriate diversity of views.

Although often overstated, the criticisms of the current process are telling. Supporters of the Administration object that members of the Senate, and private groups generally critical of the Administration, expend enormous energy not in disinterested inquiry but in trying to "catch" the nominee: to find some statement in her record that reveals a belief so extreme as to be "out of the mainstream." The hearings themselves consist of trying to get the nominee to betray views that will be unacceptable to the public at large, or, failing that, to make inconsistent statements that can be used as evidence of an unprincipled "confirmation conversion." As a result, the Administration's supporters insist, many potential candidates with distinguished records are effectively disqualified from the Court because their opponents can unfairly attack them with isolated statements they have made in the past. The result is an unduly political and sensationalistic spectacle that degrades the Court, the Senate, and the nominee.

$\dagger$ Professor of Law, University of Chicago Law School. Strauss served as Special Counsel to the United States Senate Committee on the Judiciary in connection with the nomination of Justice David H. Souter to the Supreme Court. The views expressed in this Essay are, of course, those of the authors alone.

it Karl N. Llewellyn Professor of Jurisprudence, University of Chicago, Law School and Department of Political Science. We are grateful to Akhil Amar, Elena Kagan, Jeffrey Peck, Richard Posner, and Geoffrey Stone for helpful comments on an earlier draft. Bart Aronson, Sonia Bychkov, Daniel Frank, and Thomas Marton provided valuable research assistance. 
The Administration's opponents reply that the real problem is that, for the Administration, filling vacancies on the Supreme Court has become a public relations offensive: one that consists of managing images and hiding the ball, while at the same time pushing the Court in a consistent and (to them) unhealthy direction. The President, his opponents say, chooses "stealth" nominees whom he has reason to believe are deeply conservative, but whose views the Senate will not be able to uncover. The White House then carefully prepares the nominees for the confirmation hearings, to the point where there is now practically a script: the nominee is open-minded, has "no agenda," enthusiastically accepts both Brown v. Board of Education ${ }^{1}$ and Griswold v. Connecti$c u t,{ }^{2}$ is humbled by the difficulty of being a Justice, and admires Justice Harlan. ${ }^{3}$

The nominees commit themselves to liberal-sounding principles of privacy and racial and gender justice; but the commitments are at such a high level of platitudinous abstraction that they reveal nothing about the nominees' views on controversial issues. ${ }^{4}$ And if anything potentially embarrassing surfaces from the nominees' records, the Administration's opponents say, the nominees try to distance themselves from it or to shift attention to other, more attractive aspects of their backgrounds. The consequence is a confirmation process that amounts to a media event unedifying for the public, undignified for the country, and unlikely to produce outstanding Justices or an outstanding Court.

Both of these accounts are exaggerated, but neither, unhappily, is very far from the mark. Indeed, the criticisms, though coming from sharply different sources, tend to converge. From the standpoint of the original constitutional plan, the current practice is indeed inadequate. Under the constitutional plan, the confirmation process should involve informed and tempered deliberation within the Senate, the White House, and the public at large about the best way to achieve a distinguished Supreme Court. At the very least, the President and the Senate should attempt to obtain Justices of outstanding character, of high intellectual caliber, and with qualities that will contribute something new or of particular value to the existing Court. Many members of the Senate and the Administration have tried hard to carry out this task. But it is-to understate

1. 347 U.S. 483 (1954) (invalidating segregation of public schools).

2. 381 U.S. 479 (1965) (striking down ban on use of contraceptives).

3. The near-compulsory admiration of Justice Harlan is an especially interesting development. It may be based not only on Justice Harlan's evident thoughtfulness and open-mindedness, but also on the fact that he was simultaneously (1) the most conservative Justice on the late Warren Court and (2) the preeminent intellectual source of the modem approach to substantive due process, an approach which culminated in both Griswold and Roe v. Wade, 410 U.S. 113 (1973). For a critique, see Bruce Ackerman, The Common Law Constitution of John Marshall Harlan, 36 N.Y.L. SCH. L. REV. 5 (1991).

4. A related and insufficiently noticed problem is that during the preparation for the hearings, nominees often consult closely for an extended time with officials in the Department of Justice-the most frequent litigant to appear before the nominee if she is confirmed. See "What's the Alternative?": A Roundtable on the Confirmation Process, ABA J., Jan. 1992, at 41 (remarks of Michael McConnell); see also infra note 107 and accompanying text. 
the matter-improbable that existing procedures are well suited to its fulfillment.

The unfortunate current situation has many causes, but one that is most immediately apparent is the prolonged division of the federal government between the two political parties. Nominees selected by Republican Presidents have filled the last eleven vacancies on the Supreme Court (and sixteen of the last twenty). But eight of the eleven appointments were made while the Senate was solidly controlled by Democratic majorities. Nothing remotely similar has happened before in our history. ${ }^{5}$ Despite this unprecedented situation, Republican Presidents have made ideological appointments with little senatorial opposition, even though the Senate was usually controlled by another party. Any effort to evaluate the current situation must come to terms with this striking fact.

One possible response to divided government, and to the troubled Supreme Court confirmation process it has produced, is for the Senate to be more deferential to the Administration's preferences. The Senate might confine itself to a role similar to that traditionally played by the American Bar Association and other advisory groups: to inquire into whether the nominee meets certain standards of character and professional distinction. Under this approach, the Senate could not appropriately consider a nominee's basic commitments or views on controversial issues, unless those views were so extreme as to call into question the nominee's character or competence.

Confining the Senate to this deferential role would certainly eliminate some of the current complaints about the antagonistic nature of the confirmation process, and to this extent it would be an advance. But there is not much else to commend it. From the constitutional standpoint, this recommendation seems perverse. The Constitution requires that the Senate give its "Advice and Consent" to nominations; ${ }^{6}$ this language contemplates a more active role than simple acquiescence whenever a nominee is not deeply objectionable. Beyond that, nothing in the structure of the Constitution or the nature of Supreme Court appointments suggests that the Senate should be so deferential. The Senate, no less than the President, is elected by the people. Supreme Court Justices, unlike executive branch appointees, are not the President's subordinates. Often the Court must mediate conflicts between the President and the Congress; one party to a conflict should not have the dominant role in choosing the mediator.

In our view there are other ways, more consistent with the constitutional plan, to deal with the defects of the current confirmation process. The first step is essentially the opposite of the proposal for Senate deference. We suggest that the Senate should assert its constitutional prerogatives more forcefully, unabashedly claiming an independent role. Specifically, the Senate should insist that it has both the authority to "advise" the President and the power to withold its

5. See infra Appendix.

6. U.S. CONST. art. II, $\S 2$, cl. 2. 
"consent" because it disagrees with the nominee's basic commitments on the kinds of issues that are likely to come before the Court.

When Congress considers the President's legislative initiatives, it is not deferential. No one would suggest that Congress should pass every bill the President proposes unless the bill fails some minimal test, analogous to a minimal test of character and competence. Congress is free to reject proposed legislation for political reasons. This is a most familiar part of the system of checks and balances. There is no reason for nominations to the Supreme Court to command greater deference.

At first glance it might seem that our proposal can only make matters worse. The problem, one might say, is that the confirmation process is already too partisan, too focused on ideology, too much a media spectacle, and too unmindful of the qualities of genuine distinction that Supreme Court Justices should have. We do not disagree with the premise. The current process is too ideological and partisan. But paradoxically, the best first step toward a cure-the best way to obtain distinguished Justices under current conditions-is for the Senate to assert, rather than abdicate, its role as an equal partner in the appointment process. Partisanship in Supreme Court nominations is indeed problematic. But one-sided partisanship-in which only the President, and not the Senate, is allowed to be partisan-is much worse.

The approach we recommend permits us to suggest several palliatives for the problems posed by partisanship in the confirmation process. In particular, we argue for a reduced emphasis on the role of the confirmation hearings and greater use of the Senate's "advice" function and of the pre-nomination record. The current emphasis on the hearings has produced many of the current difficulties. An independent role, combined with revisions in the process, would yield significant improvements.

In Part I of this Essay, we show how the text, history, and structure of the Constitution contemplate an independent role for the Senate. In Part II, we suggest that an independent role is especially appropriate in current conditions. In Part III, we consider several counterarguments, including the most important: that our approach would unduly politicize the process of choosing Supreme Court Justices. In this final part, we also set out some recommendations for improving the confirmation process.

\section{THE Constitution}

The Constitution fully contemplates an independent role for the Senate in the selection of Supreme Court Justices. ${ }^{7}$ Article II, Section 2 provides that

7. An especially helpful account is James E. Gauch, Comment, The Intended Role of the Senate in Supreme Court Appointments, 56 U. CHI. L. REV. 337 (1989); see also Charles L. Black, Jr., A Note on Senatorial Consideration of Supreme Court Nominees, 79 YALE L.J. 657 (1970) (arguing that constitutional considerations demand enhanced senatorial scrutiny when giving advice and consent to judicial, as opposed 
the President "shall nominate, and by and with the Advice and Consent of the Senate, shall appoint ... Judges of the supreme Court." These words assign two distinct roles to the Senate-an advisory role before the nomination has occurred and a reviewing function after the fact. The consent requirement, if the Senate takes it seriously, places pressure on the President to give weight to senatorial advice as well. At the same time, the advisory function makes consent more likely. The clause thus envisions a genuinely consultative relationship between the Senate and the President. It assumes a deliberative process, jointly conducted, concerning the composition of the Court. ${ }^{9}$

History supports this view of the text. The most explicit and elaborate contemporaneous exposition was given by George Mason in 1792. Mason wrote:

I am decidedly of opinion, that the Words of the Constitution ... . give the Senate the Power of interfering in every part of the Subject, except the Right of nominating. . . . The Word 'Advice' here clearly relates in the Judgment of the Senate on the Expediency or Inexpediency of the Measure, or Appointment; and the Word 'Consent' to their Approbation or Disapprobation of the Person nominated; otherwise the word Advice has no Meaning at all-and it is a well known Rule of Construction, that no Clause or Expression shall be deemed superfluous, or nugatory, which is capable of a fair and rational Meaning. The Nomination, of Course, brings the Subject fully under the Consideration of the Senate; who have then a Right to decide upon its Propriety or Impropriety. The peculiar Character or Predicament of the Senate in the Constitution of the General Government, is a strong Confirmation of this Construction..$^{10}$

As the records of the Constitutional Convention demonstrate, the Constitution's drafters widely shared Mason's view. The Convention had four basic options of where to vest the appointment power: it could have placed the power (1) in the President alone, (2) in Congress alone, (3) in the President with congressional advice and consent, or (4) in Congress with Presidential advice and consent. Some version of each of these options received serious consideration.

to executive branch, nominees); Luis Kutner, Advice and Dissent: Due Process of the Senate, 23 DEPAUL L. REV. 658 (1974) (arguing that Constitution calls for consultation before appointments); Charles M. Mathias, Jr., Advice and Consent: The Role of the United States Senate in the Judicial Selection Process, 54 U. CHI. L. REV. 200 (1987) (arguing that Senate needs to reconceptualize its role of advice and consent and needs to devote more resources to enhancing role).

8. U.S. CONST. art. II, \& 2, cl. 2.

9. In this way the system strikes some recurrent constitutional chords. See Joseph M. Bessette, Deliberative Democracy: The Majority Principle in Republican Government, in HOW DEMOCRATIC IS THE Constitution? 102 (Robert A. Goldwin \& William A. Schambra eds., 1980) (arguing that constitutional system of checks and balances was intended to promote deliberative government).

10. Letter from George Mason to James Monroe (Jan. 30, 1792), reprinted in 3 PAPERS OF GEORGE MASON 1255 (William T. Hutchinson \& William M.E. Rachal eds., 1970). 
The ultimate decision to vest the appointment power in the President stemmed from a belief that he was uniquely capable of providing the requisite "responsibility." A single person would be distinctly accountable for his acts. At the same time, however, the Framers greatly feared a Presidential monopoly of the process. They worried that such a monopoly might lead to a lack of qualified and "diffused" appointees, and to patronage and corruption. The Framers also feared insufficient attentiveness to the interests of different groups affected by the Court.

An important feature of the debates was the Framers' effort to design the appointments process in a way that would protect the interests of the small states. In thinking about the appointment of Supreme Court Justices, the Framers thus focused on the likelihood that nominees would be attentive to the various interests affected by the Court. Conflicts between large and small states, a principal political question of the founding period, present a much less important issue today. But there are now other conflicting interests that are profoundly affected by the composition of the Supreme Court. The Framers contemplated a senatorial role precisely to protect such interests, and to assure a degree of political oversight of the likely votes of Supreme Court nominees. The central importance of this political concern to the selection process, as that process was originally designed, strongly argues against a Presidential monopoly today.

The compromise that finally emerged-the system of advice and consent-was designed to counteract all of these various fears. Throughout the Convention, representatives of the smaller states were especially skeptical of a large Presidential role and insistent on the need for the safeguards that the Senate could provide. Representatives of the larger states, concerned with congressional partiality and lack of responsibility, sought to constrain the Senate. ${ }^{11}$ The requirement of senatorial advice and consent simultaneously responded to both sets of concerns.

\section{A. The Early Agreement on Congressional Appointment}

It is important to understand that during almost all of the Convention, the Framers agreed that the Senate alone or the legislature as a whole would appoint the judges. The current institutional arrangement emerged in the last days of the process. On June 5, 1787, the standing provision required "that the national Judiciary be [chosen] by the National Legislature."12 James Wilson spoke against this provision and in favor of Presidential appointment. ${ }^{13} \mathrm{He}$ claimed that "intrigue, partiality, and concealment" would result from legislative

11. See Gauch, supra note 7 , at 348.

12. 1 THE RECORDS OF tHE FEDERAL CONVENTION OF 1787, at 119 (Max Farrand ed., 1966).

13. Id. at 126. 
appointment, and that the President was uniquely "responsible."14 John Rutledge responded that he "was by no means disposed to grant so great a power to any single person. The people will think we are leaning too much towards Monarchy."15

James Madison agreed with Wilson's concerns about legislative "intrigue and partiality," but he "was not satisfied with referring the appointment to the Executive."16 Instead, he proposed to place the power of appointment in the Senate, "as numerous eno' to be confided in-as not so numerous as to be governed by the motives of the other branch; and as being sufficiently stable and independent to follow their deliberative judgments." 17 Thus, on June 5, by a vote of nine to two, the Convention accepted the vesting of the appointment power in the Senate. ${ }^{18}$

On June 13, Charles Cotesworth Pinckney and Roger Sherman tried to restore the original provision for appointment of the Supreme Court by the entire Congress. ${ }^{19}$ Madison renewed his argument and the motion was withdrawn. ${ }^{20}$

The issue reemerged on July 18. Nathaniel Ghorum claimed that even the Senate was "too numerous, and too little personally responsible, to ensure a good choice."21 He suggested, for the first time, that the President should appoint the Justices, with the advice and consent of the Senate-following the model set by Massachusetts. ${ }^{22}$ Wilson responded that the President should be able to make appointments on his own, but that the Ghorum proposals were an acceptable second best. ${ }^{23}$ Alexander Martin and Sherman endorsed appointments by the Senate, arguing that the Senate would have greater information and-a point of special relevance here-that "the Judges ought to be diffused," something that "would be more likely to be attended to by the $2 \mathrm{~d}$. branch, than by the Executive. ${ }^{124}$ Edmund Randolph echoed this view. ${ }^{25}$

In the end, the Ghorum proposal was rejected by a vote of six to two. At that point, Ghorum suggested, as an alternative, that the President should nominate and appoint judges with the advice and consent of the Senate. On this the vote was evenly divided, four to four. ${ }^{26}$

\footnotetext{
14. Id. at 119 .

15. $I d$.

16. Id. at 120 .

17. Id. (footnote omitted).

18. $I d$.

19. Id. at $224,232 \mathrm{n} .12$.

20. Id. at 232-33.

21. 2 id. at 41 .

22. Id.

23. Id.

24. Id.

25. Id. at 43.

26. Id. at 44 .
} 
Madison then proposed Presidential nomination with an opportunity for Senate rejection, by a two-thirds vote, within a specified number of days. ${ }^{27}$ Changing his earlier position, Madison urged that the executive would be more likely "to select fit characters," and that "in case of any flagrant partiality or error, in the nomination, it might be fairly presumed that $2 / 3$ of the $2 \mathrm{~d}$. branch would join in putting a negative on it."28 Pinckney spoke against this proposal, ${ }^{29}$ as did George Mason, who argued: "[A]ppointment by the Executive [is] a dangerous prerogative. It might even give him an influence over the Judiciary department itself."30

The motion was defeated by six to three. By the same vote, the earlier Madison proposal, in which the Senate would appoint the Justices, was accepted. $^{31}$

The issue next arose on August 23. Robert Morris argued against the appointment of officers by the Senate, considering "the body as too numerous for the purpose; as subject to cabal; and as devoid of responsibility." ${ }^{132}$ But it was not until September 4 that the provision appeared in its current form. ${ }^{33}$ Morris made the only recorded pronouncements on the new arrangement and seemed to speak for the entire, now unanimous assembly. Morris said, "[A]s the President was to nominate, there would be responsibility, and as the Senate was to concur, there would be security. ${ }^{34}$ Great weight should be given to the remarks made by Morris because of their timing. The Convention accepted the provision with this understanding.

B. The Meaning of the Shift to Presidential Appointment With Advice and Consent by the Senate

This picture leaves something of a puzzle. For almost all of the Convention, the appointment power was vested in the Senate. At the last moment, it was shifted to the President, with the advice and consent of the Senate. What accounts for the shift?

We speculate that two developments played an important role. First, on July 16,1787 , the Convention approved the Great Compromise, allowing equal representation for the states within the Senate despite their differences in population. This additional security for the small states may have provided those states with a degree of reassurance that made a Presidential initiative in the appointments process significantly less threatening. That reassurance, going

27. $I d$.

28. Id. at 80 .

29. Id. at 81 .

30. Id. at 83 .

31. Id.

32. Id. at 389.

33. Id. at 495 .

34. Id. at 539. 
to the structure of the document, may have made it less necessary to insist on limiting the President's role in appointments. ${ }^{35}$

Second, the assessment of Presidential powers appears to have changed in a major way when the Founders devised the Electoral College, thereby allowing a degree of representation of states qua states in the selection of the President. ${ }^{36}$ As we have seen, much of the resistance to Presidential power came from the small states, which feared that the President would be inattentive to their interests. Once it was decided that the President would be selected through the new, protective route, the small states had a new degree of security against the obvious risks, from their point of view, of pure majoritarianism. They therefore would have found it less threatening to vest the power of appointment in the President in the first instance. The Framers could accomplish the central goal of ensuring "responsibility" without undue risk to state interests.

But there is no evidence of a general agreement that the President should have plenary power over the appointments process. On the contrary, the ultimate design mandated a role for the Senate in the form of the advice and consent function. In this way, it carried forward the major themes of the debates. With respect to the need for a Presidential role, the new system ensured "responsibility"37 and guarded against the risk of partiality in the Senate. With respect to resistance to absolute Presidential prerogative, the principal concerns included (1) a fear of "monarchy"38 in the form of exclusive Presidential appointment; (2) a concern for "deliberative judgments", ${ }^{39}$ (3) a belief that "the Judges ought to be diffused," that is, diverse in terms of their basic commitments and alliances; (4) a fear of executive "influence over the Judiciary department itself"; ${ }^{41}$ and (5) a desire for the "security"42 that a senatorial role would provide.

As Mason's comments suggest, the Senate's role was to be a major one, allowing the Senate to be as intrusive as it chose. Even Hamilton, perhaps the strongest defender of Presidential power, emphasized that the President "was bound to submit the propriety of his choice to the discussion and determination of a different and independent body. ${ }^{, 43}$ Of course, the President retained the power to continue to offer nominees of his selection, even after an initial rejection. He could continue to name people at his discretion. Crucially, howev-

35. The argument is advanced in Gauch, supra note 7, at 347-50.

36. See Calvin C. JILlson, CONSTITUTION MAKING: CONFLICT aNd CONSENSUS IN THE FEDERAL CONVENTION OF 1787, at 171 (1988); CHARLES C. THACH, THE CREATION OF THE PRESIDENCY, 1775-1789: A STUDY IN CONSTTTUTIONAL HISTORY 97-104 (2d ed. 1969).

37. See supra note 34 and accompanying text.

38. See supra note 15 and accompanying text.

39. See supra note 17 and accompanying text.

40. See supra note 24 and accompanying text.

41. See supra note 30 and accompanying text.

42. See supra note 34 and accompanying text.

43. THE FEDERALIST No. 76, at 457 (Alexander Hamilton) (Clinton Rossiter ed., 1961). 
er, the Senate was granted the authority to continue to refuse to confirm. It also received the authority to "advise."

These simultaneous powers would bring about a healthy form of checks and balances, permitting each branch to counter the other. That system was part and parcel of general deliberation about Supreme Court membership. The Convention debates afford no basis for the view that the Senate's role was designed to be meager. On the contrary, they suggest a fully shared authority over the composition of the Court. That shared authority was to include all matters that the Senate deemed relevant, including the nominee's point of view.

As we have noted, this argument derives particular force from the centrality of the question of states' interests to the debate over the appointments process. The split between the large and small states was among the most important political issues of the period. Some delegates were fearful that all judicial nominees would come from large states. More generally, state rivalry, dominating the debates over the appointments clause, was the functional equivalent of the most sharply disputed of current legal and political debates. There can be no question that the "advice and consent" role was intended to provide, in Morris' terms, "security." And there can be no question that a central aspect of "security" was the power to refuse to confirm nominees insensitive to the interests of a majority of the states. In this sense, political commitments were understood to be a properly central ingredient in senatorial deliberations. ${ }^{44}$

\section{The Early Practice}

The practice of the Senate in the early days of the republic and thereafter attests to the same conclusion. ${ }^{45}$ George Washington's nomination of John Rutledge, then Chief Justice of South Carolina, as Chief Justice of the United States is the most revealing case in point. ${ }^{46}$ Rutledge's challenge to the Jay Treaty, ${ }^{47}$ negotiated by Washington with Great Britain, played a pivotal role in the confirmation process. The Jay Treaty was challenged by the Republicans as a concession to Britain but approved by the Federalists as a way of keeping the peace. Rutledge attacked the treaty in a prominent speech in Charleston. The Federalists sought to block the Rutledge appointment on straightforwardly political grounds. Hamilton, a leader of the support for the Jay Treaty, led the opposition to Rutledge. The Senate ultimately rejected Rutledge for political reasons, by a vote of fourteen to ten. ${ }^{48}$

44. See Gauch, supra note 7, at 363.

45. See HENRY J. ABRAHAM, JUSTICES AND PRESIDENTS: A POLITICAL HISTORY OF APPOINTMIENTS TO THE SUPREME COURT 71-94 (3d ed. 1992).

46. See LAURENCE TRIBE, GOD SAVE ThIS Honorable COURT $79-80$ (1984); Gauch, supra note 7, at $358-62$.

47. Agreement with Great Britain, Nov. 19, 1794, 8 Stat. 116, T.S. No. 105.

48. There was talk as well of Rutledge's "insanity," but this seemed pretextual. See Gauch, supra note 7 , at $360-62$. 
Nor was the Rutledge rejection unique. In 1811, the Senate rejected Madison's appointment of Alexander Wolcott, partly on the basis of political considerations. In 1826, President Adams' appointment of Robert Trimble was nearly rejected on political grounds. The 1828 nomination of John Crittenden, a Whig, was ultimately prevented through postponement, and squarely on ideological grounds. Similar episodes occurred in the first half of the nineteenth century. In fact, during the nineteenth century, the Senate blocked one of every four nominees for the Court, frequently on political grounds. ${ }^{49}$

The Senate has at times insisted on the "advice" segment of its constitutional mandate. In 1869, President Grant nominated Edwin Stanton after receiving a petition to that effect signed by a majority of the Senate and the House. ${ }^{50}$ In 1932, the Chair of the Judiciary Committee, George W. Norris, insisted on the appointment of a liberal Justice to replace Oliver Wendell Holmes. ${ }^{51}$ Greatly influenced by a meeting with Senator William Borah, President Hoover eventually appointed Benjamin Cardozo to the Court. The Senator persuaded President Hoover to move Cardozo, then at the bottom of the President's list of preferred nominees, to the top. ${ }^{52}$

\section{The Constitutional Structure}

We have established that the constitutional text and history support an independent role for the Senate in the confirmation process. In the particular context of judicial appointments, there is an additional and highly compelling concern, one that stems from constitutional structure. It may be granted that the Senate ought generally to be deferential to Presidential nominations involving the operation of the executive branch. For the most part, executive branch nominees must work closely with or under the President. The President is entitled to insist that those nominees are people with whom he is comfortable, both personally and in terms of basic commitments and values. ${ }^{53}$

49. See ABRAHAM, supra note 45, at 39-42; JOSEPH P. HARRIS, THE ADVICE AND CONSENT OF THE SENATE: A STUDY OF THE CONFIRMATION OF APPOINTMENTS BY THE UNITED STATES SENATE 302-03 (1953).

50. See ABRAHAM, supra note 45 , at 127.

51. See id. at 204.

52. See id, at 205-06.

53. This seems to follow from Myers v. United States, 272 U.S. 52, 135 (1926) (suggesting that President has power to supervise executive officers even when they are exercising discretion in their ordinary duties prescribed by statute, and power to remove them for unwise use of such discretion). The constitutional text, mandating Senate involvement in the appointment process, is identical for the Senate's review of Supreme Court and executive branch nominees. There is thus an argument from the text that an independent senatorial role is appropriate in all cases. Considerations of history and structure, however, suggest that the cases might be treated differently. The complex history summarized above, see supra notes 7-44 and accompanying text, argues strongly for an independent role for the judicial branch nominees, and it applies only to these nominees. There is no corresponding debate for executive branch nominees. As discussed in the text, the structural considerations argue against an independent role for the Senate with respect to executive branch employees, and for such a role with respect to Supreme Court nominees. See infra Part II.E. (discussing separation of powers reasons for independent investigation of judicial nominees). 
The case is quite different, however, when the President is appointing members of a third branch. The judiciary is supposed to be independent of the President, not allied with him. It hardly needs emphasis that the judiciary is not intended to work under the President. This point is of special importance in light of the fact that many of the Court's decisions resolve conflicts between Congress and the President. A Presidential monopoly on the appointment of Supreme Court Justices thus threatens to unsettle the constitutional plan of checks and balances.

Constitutional text, history, and structure strongly suggest that the Senate is entitled to assume a far more substantial role than it has in the recent past. There are analogies to proposed legislation and treaties, and to the Presidential veto. No one thinks that the Senate must accept whatever bill or treaty the President suggests simply because it is a "competent" proposal; it would be odd indeed to claim that the President must sign every bill before looking closely at the merits. Under the Constitution, the role of the Senate in the confirmation process should be approached similarly.

\section{The Senate's ROle In AN ERA OF DIVIDED GOVERNMENT}

For much of the twentieth century, the Senate has not made independent judgments of the kind we urge for Supreme Court nominees. Until 1968, only one nominee had been rejected by the Senate in this century. ${ }^{54}$ There is some controversy over exactly how independent a role the Senate played in the nineteenth century. 55

But since 1969, circumstances have changed. Current conditions-conditions that are unique in our history-justify a more active role for the Senate. ${ }^{56}$ These circumstances include a large number of consecutive appointments by Presidents of one party during a period of divided government; the danger of intellectual homogeneity on the current Court; overt ideological attacks by the President on the Court and the self-conscious screening of

54. See ELDER WITT, GUIDE TO THE U.S. SUPREME COURT 995-98 (1990).

55. See TRIBE, supra note 46 , at $58-59$.

56. In the last 23 years, two nominees have been withdrawn to avoid Senate defeats (Fortas and Ginsburg) and three have been defeated (Haynsworth, Carswell, and Bork). Thus, the Senate has stopped Presidential nominees in 5 of 16 attempts, which amounts to 31\%, a high percentage. However, no understanding has emerged on the part of the Senate that it is entitled to undertake an independent inspection of the nominee's likely voting record. Indeed, it appears that many Senators believe that such a role would be unacceptable. See, e.g., 137 CONG REC. S9295 (daily ed. July 9, 1991) (statement of Sen. Grassley); 136 CONG. REC. S14,360 (daily ed. Oct. 2, 1990) (statement of Sen. McConnell); 136 CONG. REC. S12,872 (daily ed. Sept. 12, 1990) (statement of Sen. Hatch); 133 CoNG. REC. S14,913 (daily ed. Oct. 23, 1987) (statement of Sen. Domenici); 133 CONG. REC. S10,537 (daily ed. July 23, 1987) (statement of Sen. Dole).

All in all, there is no clear current understanding on the part of the Senate of its appropriate role in the confirmation process. No sharply defined view has materialized on this question. There is, however, a discernible shift in the direction suggested in this Essay. See, in particular, the proposed Senate Resolution introduced by Senator Simon, calling for "philosophical balance" as a relevant consideration in selecting nominees and requesting "informal, bipartisan consultation with some members of the Senate" before nomination. S. Res. 194, 102d Cong., 1st Sess., 137 CoNG. REC. S14,712 (daily ed. Oct. 15, 1991). 
nominees to the Court by the executive branch; the effective exclusion of the Senate from the selection of lower federal court judges; and the increased importance of separation of powers questions. Under these conditions, deference by the Senate is likely to produce neither a Court of high quality nor a Court with the appropriate range of views. ${ }^{57}$

\section{A. Eleven Consecutive Appointments During a Period of Divided Government}

The most important circumstance is, of course, prolonged divided government-specifically, the eleven consecutive Republican appointments, all made while the Democrats controlled the House, nine while the Democrats controlled the Senate..$^{58}$

American politics has not, in general, been characterized by the alternation of parties in power. ${ }^{59}$ Republicans dominated the national government between the Civil War and the New Deal. ${ }^{60}$ Democrats then dominated until $1968,{ }^{61}$ and Republicans have won five of the last six Presidential elections.

Even so, it is nearly unprecedented for one party to fill eleven consecutive vacancies. ${ }^{62}$ This is partly the result of the fact that President Carter was the

57. The Senate is always entitled to take an independent role and to consider likely voting patterns. It is free to do so even in a period in which the same party controls the Senate and the Presidency. But the argument that such a role would be a structural imperative of the constitutional plan-as opposed to constitutionally authorized-would be far weaker in that event, for reasons set out below. See infra Parts II.A, II.E. The argument for an independent role would be further weakened if the Court were not, in the relevant sense, monolithic. A Court with a balance of respectable views, see infra Part II.F, poses a far less urgent case for careful inspection by the Senate of likely voting pattems. For these reasons, we believe that the case for an independent role is currently far stronger than it was, for example, at the time of the nomination of Judge Robert Bork.

Things would be different if one party controlled both the Senate and the Presidency. For example, there would be little need for a Democratic Senate to undertake an independent investigation of the nominee of a Democratic President-not because the Democratic view is "correct," but because there would be a reduced need for the Senate to serve as an ideological check on the President. (Of course, competence and character would remain relevant.) Almost none of the arguments would be relevant if a Democratic President in (say) 1994 offered nominations to a Democratic Senate. Yet another question would be raised if a Republican Senate in 1994 were confronted by a nominee from a Republican President. Here some of the arguments we offer would remain relevant, but others would cease to be compelling.

58. Republican Presidents filled vacancies created by 10 Justices who left the Court, and elevated William Rehnquist from Associate Justice to Chief Justice. Because of the Chief Justice's influence and the controversy surrounding the Rehnquist elevation, we count this as eleven appointments.

59. The principal exception to this is the period before the Civil War. See infra Appendix.

60. Of the 13 Presidents who served in office from 1868, when Ulysses S. Grant succeeded Andrew Johnson, until 1932, when Franklin Roosevelt defeated Herbert Hoover, 11 were Republicans. The exceptions were Grover Cleveland, elected in 1884 and 1892, and Woodrow Wilson, elected in 1914 and 1918. See infra Appendix.

61. Between 1932 and 1968, Democrats won seven of nine Presidential elections; the only exception was a war hero, President Eisenhower. See infra Appendix.

62. From Abraham Lincoln until Grover Cleveland, Republicans appointed 14 consecutive Justices. (During part of this period, the Court had 10 Justices.) Presidents Franklin D. Roosevelt and Harry S. Truman made 13 consecutive appointments. (They filled 12 vacancies and elevated Harlan Fiske Stone from Associate Justice to Chief Justice.) President George Washington, of course, appointed the entire membership of the Court, then six Justices. He and President John Quincy Adams, both members of the Federalist Party, made a total of 13 consecutive appointments. At no other time have Presidents from one party appointed more than nine consecutive Justices. See infra Appendix. 
only President in history to serve a full term without making a single appointment. ${ }^{63}$ More important, however, most of these appointments have been made while the Democrats thoroughly controlled Congress. In the past, one party has tended to dominate national politics entirely, controlling both elected branches. The last quarter-century of divided government is genuinely unique in our history. ${ }^{64}$

To be sure, the Supreme Court is supposed to be independent of the political controversies of the moment. Its independence is reflected in the constitutional provisions for life tenure and nondiminution of salary. ${ }^{65}$ The Court should not track popular opinion; its duty is to interpret the Constitution. But the constitutional plan insulates the Court only to a certain extent. The Constitution makes the Court responsive to popular sentiment as well. The desire for responsiveness is reflected in a selection process in which the President and the Senate play crucial and mutually constraining roles. ${ }^{66}$ The Constitution responds to the risk that a Court whose members serve for life may grow too far out of touch with societal convictions. The Constitution ensures that the Court will in a certain sense be attuned to the prevailing interpretive aspirations of the public at large. ${ }^{67}$

When the people over time elect Presidents of different parties, and Presidents of each party contribute to the Court, this function is well served. The Court's membership then has some connection with the political balance in the country. When, as during the Roosevelt and Truman Administrations and during most of the post-Civil War period, the people turn over both Congress and the Presidency to one party, this function is again served, though in a different way. The Court does not reflect a balance between the parties-because there is no such balance in the country. Rather, the Court reflects the dominance of one side of the debate. After 1936, for example, the New Deal "won"; 68 the nation

Of course, in these instances, the same party controlled both the White House and the Senate-a crucial difference from current circumstances, as we explain in the text. President Washington was not formally a member of any party, but he was generally thought to be affiliated with the Federalists, who controlled the Senate during his administration. See JOHN C. MILLER, THE FEDERALIST ERA 122-24 (1960).

63. See infra Appendix.

64. Id.

65. U.S. CONST. art. III, $\S 1$.

66. See U.S. CONST. art. II, $\$ 2$, cl. 2; supra notes 7-9, 43-44 and accompanying text.

67. We do not suggest that the Court should "follow th' ilection returns," in Mr. Dooley's words. GeOFFRey R. StONE ET AL., Constitutional LAW 76-77 (2d ed. 1991) (Mr. Dooley was Finley Peter Dunne's pen name). We claim only that there is reason for concern when the Court is dominated by one branch and unchecked by another of similar electoral pedigree. In general, we put to one side the questions of what counts as "too far out of touch," and of what is the proper relationship between existing political convictions and judicial interpretations. The proposition in the text need not depend on controversial answers to these questions.

Of course, it is true that in certain circumstances a Court would do well to be quite out of touch, as in a case in which both elected branches were censoring political speech. In this sense, there are substantive constraints on the sorts of political convictions that properly influence constitutional interpretation, but those substantive constraints do not argue against our proposal here.

68. See Bruce Ackerman, Constitutional Politics/Constitutional Law, 99 YALE L.J. 453, 511 (1989) ('When the New Dealers gained a crushing victory in the Presidential and congressional elections of 1936, 
was thoroughly committed to it, and Democrats dominated both branches. The Court, with thirteen consecutive appointees by Democratic Presidents, properly reflected the fact that the nation had made up its mind. ${ }^{69}$

But in the last twenty-five years the nation has not made up its mind. It has elected mostly Republican Presidents, but mostly Democratic Senates. The composition of the Supreme Court played a role in Presidential campaigns, and it is possible that this issue helped settle the elections as well. We know of no evidence that the composition of the Court has ever played a significant role in either Presidential or senatorial elections. Of course, it is theoretically possible that people voted for Republican Presidential candidates because they wanted a certain kind of Supreme Court; but it is also possible that the composition of the Court played a role in senatorial elections. Any relevant mandate is therefore quite muddled.

In any case, the country has not reached closure on the questions of constitutional method or constitutional result that were raised in the Warren Court, the Burger Court, and the Rehnquist Court. On the contrary, the country is deeply divided. In these circumstances, if the Court is to stay in touch with public convictions (in the limited way that the appointment power envisions), it should not reflect only the President's views. It should reflect the Senate's as well.

\section{B. Overt Ideological Attacks on the Court by the President}

A series of appointments by one party will not necessarily reflect that party's ideology. ${ }^{70}$ Some appointments in the history of the Court have been indisputably nonideological and nonpartisan; sometimes Presidents simply sought a distinguished figure. ${ }^{71}$ In such cases, the members of the Senate, even in a period of divided government, cannot complain that their mandate from the people is being ignored by the President.

they claimed a mandate from the People in support of their new activist vision of American govemment.").

69. Of course, the nation may have wrongly made up its mind, and in that case the Court's approach to the Constitution after the Democratic appointments could be understood as a capitulation. But until the nation revisits this question, there is no practical means to control this problem, if indeed it is a problem.

70. We use the words "ideology" and "politics" at various points in this Essay. By using such words, we do not intend to take any controversial position about the nature of reasoning in constitutional law. Certainly we do not mean to identify constitutional law with "politics" or "ideology" or to claim that legal reasoning is reducible in that way. But we do believe that it is much too simple to think that the interpretive views of the Reagan and Bush Administrations are simply "faithful to the Constitution," whereas the interpretive views of Justices such as Earl Warren and Hugo Black represented "an abandonment of the Constitution." We insist only that there is a spectrum of reasonable, good faith interpretive positions and that under current conditions it is implausible to think that only one of these positions warrants participation in judicial and public debate.

71. Justice Cardozo is a good example. See TRIBE, supra note 46 , at $80-81$. Justice Stevens may be another. We recognize, however, that some would dispute the claim that there are any appointments that are truly nonpolitical. A nomination based purely on quality and character would be hard to imagine. Some people of outstanding ability and outstanding character also have views that are unacceptably extreme, and they are therefore unappointable. 
The eleven consecutive Republican appointments do not, in general, fit this description. Those appointments were made by four Presidents-Nixon, Ford, Reagan, and Bush. Each of these Presidents campaigned on a platform that specifically condemned certain Supreme Court decisions. ${ }^{72}$ Each of these Presidents (President Ford to a lesser extent than the others) vigorously criticized the Court during his campaign and again during his Presidency. ${ }^{73}$

We do not argue that this is necessarily an inappropriate thing for a President to do. Concerns of this sort can be a fully legitimate part of the nomination process. Nor do we contend that the resulting nominees have been undistinguished. But when a President has criticized the Court so strongly on such grounds, the President's appointments can be counted on to reflect his own commitments. When the people elect a Senate with different convictions from those of the President, there is no reason for the appointments to reflect the President's views alone. Under the constitutional plan, the Senate need not sit idly by while a consistent stream of Presidential appointments leads the Court in a direction of which it disapproves.

\section{Screening of Nominees by the Administration, With a View Toward Likely Voting Patterns and Judicial Commitments}

If the President, regardless of his statements during a campaign, deliberately sought to make nonpartisan appointments, the Senate would have much less warrant for injecting concerns about likely voting patterns. But with two arguable exceptions-Justices Stevens and Powell ${ }^{74}$ - there can be little doubt that recent Republican Presidents have made appointments on the basis of their criticisms of the Court, attempting to fill vacancies with people with certain predictable commitments. We do not suggest that there has necessarily been a "litmus test" on such issues as abortion or affirmative action. But it seems

72. There were "planks" involving Roe v. Wade, 410 U.S. 113 (1973), and Miranda v. Arizona, 384 U.S. 436 (1966). See 2 NATIONAL PARTY PLATFORMS 868, 972, 976 (Donald B. Johnson ed., 1978) (1972 and 1976 platforms); NATIONAL PARTY PLATFORMS OF 1930, at 183, 189 (Donald B. Johnson ed., 1982); OFFICIAL REPORT OF THE PROCEEDINGS OF THE THIRTY-FOURTH REPUBLICAN NATIONAL CONVENTION 343 (1988).

73. See 1970 PUBLIC PAPERS OF THE PRESIDENTS OF THE UNTTED STATES: RICHARD NIXON 937; 1969 id. at 818; 1983 PUBLIC PAPERS OF THE PRESIDENTS OF THE UNITED STATES: RONALD REAGAN 876; Bernard Weinraub, Bush Seeking Way to Circumvent Court's Decision on Flag Burning, N.Y. TnES, June 27,1989 , at A1. Criticism of the Court by the President is not a Republican monopoly. President Roosevelt was at least as strongly critical:

[We] have, therefore, reached the point as a Nation where we must take action to save the

Constitution from the Court and the Court from itself. . . . We want a Supreme Court which will

do justice under the Constitution-not over it. . . . This plan will save our National Constitution

from hardening of the judicial arteries.

Franklin Delano Roosevelt (radio broadcast, Mar. 9, 1937), in GERALD GUNTHER, CONSTITUTIONAL LAW 123 (12th ed. 1991).

74. Both of these men were known for a high degree of professionalism, and neither was thought to be easily identifiable with partisan considerations. Both, however, were expected to vote as conservatives or moderate conservatives. 
indisputable that these Presidents have generally attempted to choose Justices with predictable views about the role of the Court, and whose positions on the most controversial issues facing the Court were likely to conform to the President's own views.

President Nixon did not attempt to conceal the real bases of his appointments. When he announced the appointments of Chief Justice Burger and Justice Blackmun, for example, he said that one of his reasons for choosing them was to change the Court's direction in criminal procedure cases. ${ }^{75}$ Nixon said his appointees shared his conservative judicial philosophy in contrast to the "activist" philosophy of the Warren Court, obviously referring to their basic judicial orientation, especially in such areas as race discrimination and criminal procedure. ${ }^{76}$

In the Reagan and Bush Administrations, the screening of Justices has been institutionalized. (The same is true of federal lower court judges, an important point we consider below.) Officials in the Department of Justice and the White House have played a prominent role in selecting Justices. ${ }^{77}$ The public statements of Presidents Reagan and Bush have also generally confirmed that the nominees were chosen because of their conceptions of the appropriate judicial role. $^{78}$

\section{The Effective Exclusion of the Senate from the Selection of Lower Federal Court Judges}

During the last few years, the Senate has been effectively excluded from the selection of lower federal court judges. This aspect of the current situation is not widely noted, but it adds to the case for Senate independence in the selection of Supreme Court Justices. In the last twenty-five years, there have been two very significant changes in the composition of the courts of appeals. First, the size of those courts has expanded enormously. Second, the Adminis-

75. See, e.g., 1969 PUBLIC PAPERS OF THE PRESIDENTS OF THE UNTED STATES: RICHARD NIXON 396.

76. See, e.g., $1969 \mathrm{id}$. at 396; $1971 \mathrm{id}$. at 1055.

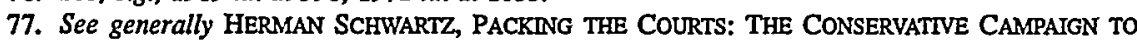
REWRITE THE CONSTITUTION 58-149 (1988); see also Sheldon Goldman, The Bush Imprint on the Judiciary, 74 JUDICATURE 294 (1991) (describing selection process under Bush); Sheldon Goldman, Reagan's Judicial Legacy: Completing the Puzzle and Summing Up, 72 JUDICATURE 318 (1989) (describing selection process under Reagan). For example, the Reagan Administration created the Committee on Federal Judicial Selection, and White House Counsel C. Boyden Gray currently chairs it. Id.

78. See, e.g., Linda R. Campbell, Health May Be Fading, But Marshall's Wit Still Sharp, CHI. TRIB., June 29, 1991 at 1 (President Bush says that he would replace Justice Marshall with "somebody that would be seen as keeping with the judicial philosophy that I've always expounded ... interpretation, not legislation"); David Hoffman, Reagan Relied on His Instincts, WASH. POST, June 18, 1986, at Al (Administration officials say that President Reagan's primary goal in selection of Rehnquist as Chief Justice was Rehnquist's agreement with President's philosophy of judicial restraint); Steven R. Weisman, Reagan Aides Say 'Short List' of Candidates for Court Is Ready, N.Y. TMES, July 1, 1981, at A19 (White House officials make clear that President Reagan wants a nominee "to be compatible with his overall philosophy of judicial restraint"). 
tration now systematically screens lower federal court judges on several grounds, including the way they are likely to vote.

In 1968, there were 83 court of appeals judges. ${ }^{79}$ As late as 1978, there were 95 court of appeals judges. ${ }^{80}$ Now there are $154 .{ }^{81}$ The turnover rate is, correspondingly, much greater today. As a result, it is essentially impossible for the Senate effectively to monitor the composition of the federal courts of appeals.

The executive branch, using a variety of formal and informal networks, can track potential judicial nominees for years, observing their development and assessing their orientation on issues likely to come before the courts. When a vacancy occurs, the Administration can move quickly to nominate a person who is already relatively well known to it. The Senate will not have nearly the same degree of familiarity with the nominee. Moreover, while the executive branch has as much time as it needs to study a person before appointing her, the Senate has little time to act: once the President has nominated someone to fill a vacancy, the Senate cannot delay its decision for long without appearing irresponsible. Even if the Senate did mobilize its resources, study the nominee, and decide to reject her, it would have to repeat the process all over again with another nominee who was known to the Administration but not to the Senators. In theory, the Senate could establish a duplicate bureaucracy and investigate each nominee to the lower courts as thoroughly as it wished. But the expense, and the political costs of the delay, would be prohibitive.

The result of the institutionalized screening of lower federal court judges is that the Administration can effectively fill the lower courts with judges committed to its basic views, and the Senate is virtually powerless to resist. Again, we do not argue that it is always inappropriate for the President to seek ideologically compatible nominees for the lower courts. Screening of this sort might, on the whole, produce nominees more capable than those produced by the patronage system that characterized earlier times. ${ }^{82}$ If the Senate shared the President's basic orientation, then executive branch screening might not necessarily be a bad thing. ${ }^{83}$ But when the country is divided on certain issues, it is difficult to see why the federal judiciary should be monolithic on the matters over which divisions persist. ${ }^{84}$

79. 1968 ANNUAL REPORT OF THE DIRECTOR OF THE ADMINISTRATTVE OFFICE OF THE UNITED STATES CourTs 90.

80. $1978 \mathrm{id}$. at 128.

81. 947 F.2d vii-xxxii (1992).

82. Even now the President sometimes pays considerable attention to the views of the Senator from the state in which the appointment will be made. But this holdover from the patronage system is no substitute for more general senatorial participation.

83. The point raises some complex issues about the relationship between the Court and existing convictions within the political process. See supra notes 68-69 and accompanying text.

84. See supra Part II.A. As a matter of constitutional text and structure, there is no barrier to an independent senatorial role in the nomination of lower court judges; there is no difference for these purposes between the Supreme Court and the lower courts. The Senate is perfectly entitled to look carefully at nominees to the lower courts as well. We do not, however, argue for such a role in light of the evident 
Because the Senate is essentially unable to affect the composition of the lower courts, Supreme Court appointments are even more important today than in the past. They are the Senate's only realistic opportunity to influence the orientation of the federal judiciary. Unlike an appointment to a court of appeals, a Supreme Court appointment is so infrequent and so important that the Senate can afford to invest the resources needed to investigate nominees thoroughly. If the Senate is not willing to take an independent look at Supreme Court nominees, however, then a committed executive is free to dominate the entire federal judiciary.

\section{E. The Increased Importance of Separation of Powers Issues}

As one would expect, the era of divided government has given rise to an unusually large number of disputes between the branches. Often the Court must resolve disputes involving the allocation of power between the President and the Congress. The constitutionality of the independent counsel provision of the Ethics in Government Act of $1978,{ }^{85}$ the Gramm-Rudman-Hollings Act, ${ }^{86}$ and the Sentencing Commission ${ }^{87}$ are recent illustrations. In the future, there is likely to be litigation over the constitutionality of institutional arrangements designed to limit Presidential control of the administrative process. ${ }^{88}$

The problem, however, goes much deeper. Recurring and now sharply debated issues of statutory construction have raised important conflicts between the executive branch and the Congress. Such issues include, most notably, the role of legislative history in statutory interpretation ${ }^{89}$ and the degree of deference to be given to administrative interpretations of statutes. ${ }^{90}$ In the resolution of such conflicts lies much of the de facto power of the executive branch and the legislature. For example, there would be a large increase in executive power, in some ways at the expense of the Congress, if the Supreme Court were to hold that legislative history is irrelevant and that administrative interpretations prevail in the face of any slight ambiguity in the statutory text.

burdens of time and resources that such a role would entail.

85. Pub. L. No. 95-521, 92 Stat. 1820 (codified as amended at 28 U.S.C. $\$ \S 49,591$ (1988)); Morrison v. Olson, 487 U.S. 654 (1988) (upholding independent counsel provision).

86. Balanced Budget and Emergency Deficit Control Act of 1985, Pub. L. No. 99-177, 99 Stat. 1038 (codified as amended at 2 U.S.C. § 901 (1988 \& Supp. II 1990)); Bowsher v. Synar, 478 U.S. 714 (1986) (invalidating Comptroller General provision of Gramm-Rudman-Hollings Act).

87. See Sentencing Reform Act of 1984, Pub. L. No. 98-473, ch. 2, 98 Stat. 1987 (codified at 18 U.S.C. $\S \S 3551-3673$ ) (1988); 28 U.S.C. $\$ \S 991-998$ (1988)); Mistretta v. United States, 488 U.S. 361 (1989) (upholding creation of Sentencing Commission).

88. See, e.g., S. 1942, 102d Congress, 1st Sess. (1991) (imposing various constraints on process of Presidential review of regulations).

89. See, e.g., Green v. Bock Laundry Mach. Co., 490 U.S. 504, 527-30 (1989) (Scalia, J., concurring in judgment); United States v. Stuart, 489 U.S. 353, $371-77$ (1989) (Scalia, J., concurring in judgment).

90. See Chevron U.S.A., Inc. v. Natural Resources Defense Council, 467 U.S. 837 (1984). 
The Court will undoubtedly confront all of these questions in the next decade. The Civil Rights Act of $1991,{ }^{91}$ for example, may raise important questions about the role of legislative history in statutory interpretation. ${ }^{92}$ There may be a new array of arrangements in which Congress attempts to participate in the implementation of federal law or to limit the President's power to control implementation. The degree of deference owed to administrative interpretations remains sharply disputed. These cases will raise difficult and fundamental questions about governmental structure.

Traditionally the Court has functioned as a mediator between the branches. But it cannot perform that function well if one branch sees the appointment process as an opportunity to put sympathetic Justices on the Court, while the other branch simply defers to the nomination of anyone whose views are not demonstrably extreme.

\section{F. The Danger of Intellectual Homogeneity on the Court}

Other things being equal, the Court benefits when it is composed of Justices with a range of views. The qualifier is important: we do not mean to suggest that the Court should have a member who believes that Brown v. Board of Education $^{93}$ should be overruled, or who considers welfare laws unconstitutional. $^{94}$ But with respect to a significant number of issues, the Court can perform its task better if there is a diversity of opinions.

This point is especially important today because Justice Marshall's retirement has deprived the Court of a distinctive voice, perhaps its last liberal voice. Of course, categories like "liberal" are contestable. But it is clear that no one now on the Court fully shares Justice Marshall's orientation. ${ }^{95}$ For several reasons, even those who disagree with Justice Marshall should consider his retirement an unfortunate development-just as the loss of the last distinctively conservative voice would be an unfortunate development. These reasons also suggest why it is fundamentally incorrect to say that when the Court is predominantly of one view, it does not matter whether the ninth Justice holds another view.

First, because the Supreme Court's jurisdiction is discretionary, the Justices' ability to identify problems in the legal system is in some ways as important as their ability to decide fully briefed cases. Judges with distinctive views notice

91. Civil Rights Act of 1991, Pub. L. No. 102-166, 105 Stat. 1071.

92. See Paul Gewirtz, Discrimination Endgame, NEw REPUBLIC, Aug. 12, 1991, at 18; Paul Gewirtz, Fine Print, NEw REPUBLIC, Nov. 18, 1991, at 10.

93. 347 U.S. 483 (1954).

94. This is so for a combination of reasons: neither of these positions is intellectually respectable, in the sense that plausible arguments cannot be brought forward on its behalf; and each position lacks any significant support within the professional community.

95. Justice Blackmun, the most liberal of the Court's Justices, is generally conservative on issues of criminal procedure. Justice Stevens is difficult to characterize as liberal or conservative. Nor do we deny that all of the Justices at some points depart from what might be predicted. 
legal problems that other judges do not see-not through ignorance or malice, but because of differing priorities. Once an issue is brought to general attention, everyone might agree on what the outcome should be. But the issue might not have come to the Court's attention at all were it not for the distinctive concerns of one of the Justices. The certiorari process has often benefitted from intellectual diversity of this kind, and it is important that it continue to do so.

Second, the Court's internal deliberations will suffer if the Court does not consist of Justices with differing views. If they are willing to listen, judges of one general outlook will learn a great deal from those with other basic orientations. Notably, one of the most significant theoretical contributions of the founding period consisted of the insistence, by the Federalists against the AntiFederalists, that heterogeneity could be a creative and productive force. As Alexander Hamilton wrote in The Federalist, "the jarring of parties ... often promote[s] deliberation." ${ }^{196}$ One need not romanticize the real-world consequences of internal deliberation in order to suggest that differences in perspective often improve both the collective reasoning process and the outcomes.

Litigants alone cannot provide the necessary perspective. The quality of advocacy before the Court is uneven, and even the best advocate usually plays only a limited role in comparison with a member of the Court. Divergent views should be presented, and pressed, during internal deliberations, when the Court is formulating results and reasons. In this regard, litigants are inevitably inadequate.

Finally, throughout American history, dissenting opinions have helped Congress and the President-and even future generations-formulate their responses to the Court. ${ }^{97} \mathrm{~A}$ Court that lacks a liberal voice-or a conservative one-would not carry out these educative tasks as well. It is hard for the American public to think about what the Court is doing if cases include no opinions presenting different sides.

There remains the question of what counts as diversity, and of when a "diverse" view is so extreme as to be unacceptable. These questions are hard to answer in the abstract. On the one hand, the current Court is by no means monolithic in the sense that all of its members agree on everything important. In any nine-member body, there will be genuine disagreements. And, as we said, we do not think that the Court is insufficiently diverse because it lacks anyone who believes, for example, that Brown v. Board of Education ${ }^{98}$ is wrong, or that the Constitution requires revolutionary socialism. On the other hand, the current Court now lacks any member fundamentally committed to the

96. See THE FEDERALIST No. 70, at 427 (Alexander Hamilton) (Clinton Rossiter ed., 1961).

97. See, e.g., Roe v. Wade, 410 U.S. 113, 171 (1973) (Rehnquist, J., dissenting); Gitlow v. New York, 268 U.S. 652, 672 (1925) (Holmes \& Brandeis, JJ., dissenting); Abrams v. United States, 250 U.S. 616, 624 (1919) (Holmes, J., dissenting); Lochner v. New York, 198 U.S. 45, 74 (1905) (Holmes, J., dissenting); Plessy v. Ferguson, 163 U.S. 537, 552 (1896) (Harlan, J., dissenting); The Civil Rights Cases, 109 U.S. 3, 26 (1883) (Harlan, J., dissenting).

98. 347 U.S. 483 (1954). 
views on constitutional method and constitutional results represented by judges like Hugo Black, William Brennan, William Douglas, Thurgood Marshall, and Earl Warren. These views cannot be characterized as marginal or as having nothing valuable to offer on their behalf. They have substantial support in the state and federal judiciaries, and from the public, Congress, professionals, and academics. Views of this sort provide a valuable perspective to the Court.

For present purposes, however, we do not have to define the boundaries of the acceptable diversity of views. The need for a diversity of views on the Court strongly argues in support of the position we advance: namely, that the Senate should take an independent role in Supreme Court nominations. In a period of divided government, Senate independence will naturally produce a diversity of views on the Court. When the nation has made up its mind about an issue-as the nation did about the New Deal in the late 1940's and as it has today about Brown -individuals who are at odds with the national consensus will find no support in either the Senate or the Administration. ${ }^{99}$ Where the nation has not made up its mind-as ours has not, for example, about affirmative action, abortion, sexually explicit speech, or the separation of church and state-an independent Senate role will ensure that the Court is not monolithic, and that its deliberations have the quality that will be absent if there is no serious encounter with divergent views.

All of these considerations suggest that, under current circumstances, the Senate should undertake an independent role in evaluating nominees to the Supreme Court. ${ }^{100}$ The Senate is entitled to insist that the next nominee be a "liberal" or a "moderate." It should not perceive itself as constrained by the Presidential election to confirm all minimally competent nominees who are not "out of the mainstream." In the words of the Constitution, the Senate is entitled to claim that it will not confirm any President's nominee unless there has been a process involving "advice" as well as "consent."

\section{A POLITICIZED PROCESS?}

We suspect that the principal source of concern about an independent Senate role is not that it would be inconsistent with the Constitution. Rather, the concern-and it is obviously an important one-is that an independent Senate role would unduly politicize the process of choosing Justices, thus

99. Sometimes, of course, a judge whose convictions diverge from the national consensus might well be desirable if the judge's own convictions are based on good reasons. Part of the point of judicial independence is to allow this phenomenon to occur. But it seems hard to design an appointments process that would systematically produce such judges.

100. The Senate is a diverse body. Its members do not have a single view about the appropriate role of the Supreme Court. The same is true of any party that controls the Senate. For example, there are sharp disagreements among current Democrats about the appropriate role of the Court on such issues as affirmative action, abortion, and sex discrimination. But these disagreements do not argue against an independent role for the Senate. They suggest only that each Senator should feel free to examine and to vote on the basis of his or her convictions. 
exacerbating the serious difficulties of the current situation. In fact, however, there is good reason to think that the approach we suggest would result in a less politicized appointment process, and one less likely to have the other undesirable characteristics that have led to so much dissatisfaction. In addition, as we will discuss, there are ways to help limit any adverse effects of an independent Senate role.

\section{A. The Process Is Already Politicized}

As we have shown, many Presidents, including most of those who appointed the last eleven Justices, more or less overtly considered a candidate's likely voting patterns in choosing a nominee. Under the current understanding, the process is political in this sense, but only at one end: the President is free to choose as conservative a nominee as he thinks he can get away with, but in order to reject the nominee the Senate must do more than merely object to the nominee's political or legal orientation. In order to reject a nominee, the Senate has to find some major deficiency in character or has to brand the nominee as "out of the mainstream."

There is no question that, if the Senate were to assume the independent approach we suggest, Senators would have to be prepared to make judgments about how nominees would be likely to vote if they became Justices. In this sense, our approach might add elements to the process that can be characterized as "political." But part of what has politicized the process is the approach of recent Presidents. ${ }^{101}$ Requiring the Senate to be nonpolitical will not cure that. ${ }^{102}$

A nonpolitical appointment process (leaving aside the question of what that might mean ${ }^{103}$ ) might be far better than one in which both the President and the Senate unabashedly focus on a nominee's likely votes. But a nonpolitical process will not come about simply because the Senate abstains. And while there is much to be said for a process that is not politicized, there is little to be said for a process in which one side to a partisan debate is free to consider likely voting patterns, while the other is supposed to remain indifferent to them. This is especially the case in a prolonged period of divided government, when Presidents have criticized the Court on political grounds and have self-consciously tried to shift its course.

101. Another part is the role of the Supreme Court in American government, but an analysis of that role would require a longer discussion than we can provide here.

102. Our approach would indeed politicize the process in the sense that unlike a posture of deference, it would produce a kind of open and sustained public debate over nominees-often prolonged, sometimes misleading and confusing, and in many respects "political." But this is a proper, if not always well designed, aspect of the system of checks and balances, and indeed of democracy itself.

103. See supra note 71. 


\section{B. How an Independent Senate Role Might Ameliorate the Current Problems of the Appointment Process}

More important, there is reason to think that our approach would actually make the process less political. We do not want to overstate this point, which is somewhat speculative. But ironically, a system in which only one side is free to be political might inject more politics into the appointment process than a system in which the two sides battle on equal terms.

If the Senate insists on its "advice" function, there will be a greater likelihood of bipartisan agreement before the nomination is made. A Senate willing to provide "advice" should allow its leadership to meet with the President and other executive branch officials before a nomination is made. Influential Senators might well provide a list of preferred or acceptable candidates. They should certainly have an opportunity to review and comment on possible Presidential choices, with a power to "veto" before the fact those potential nominees of whom they most strongly disapprove. Such a system might well move toward a genuinely deliberative process in which Senators and executive branch officials talk together about future nominees. Such consultations might reduce or even eliminate many of the current problems.

Moreover, if the Senate is free to consider a nominee's views openly, the President will have a greater incentive to compromise on the choice of the nominee. The Senate will also have more reason to confirm such a compromise nominee without searching for out-of-context statements, trying to catch the nominee in a damaging admission, and the like. As matters stand now, the President has a strong incentive to choose a nominee who is very conservative, but who will be difficult to defeat. So long as the Senate is not openly concerned with the nominee's views in the same way as the President is, but confines itself to the nominee's "acceptability"- that is, to whether the nominee has good character and is not an extremist-the President has limited incentives to compromise on the choice. Instead, the ideal nominee is one who strongly agrees with the President, but who cannot be portrayed as unacceptable.

By the same token, so long as the Senate is not unabashedly free to consider likely voting patterns, it will have to find other ways to try to defeat nominees it actually opposes on these grounds. This is the dynamic that generates many of the practices that critics of the Senate deplore. We do not want to suggest that it is inappropriate for the Senate to take a careful look at a nominee's character and integrity. Matters of character can and should disqualify even a nominee of great legal distinction. But the confirmation process unquestionably has a tendency to exaggerate the importance of isolated statements from, for example, judicial opinions or academic articles written years earlier by the nominee. To some extent that exaggeration comes about because the Senate is, in effect, sublimating its legitimate concern with the nominee's judicial convictions. 
If the Senate were free to oppose a nominee explicitly because it disagreed with those convictions, ${ }^{104}$ the President would have a stronger incentive to compromise by selecting a nominee whose views were more in keeping with those of the Senate. In the current climate, under the approach we advocate, it is not at all implausible that the President and the Senate might agree on a moderate nominee of genuine distinction. The President, knowing that he could not rely on the confirmation of an extreme conservative, might find such a nominee the second-best choice. The Senators, knowing they had done all they could to obtain a more moderate nominee, would have less incentive to attack the nominee's record in ways that might be unfair. Both sides, having checkmated each other on this dimension, might be more concerned with the nominee's qualities of intellect and vision.

In the long run, this interaction might be exceedingly healthy. Assume, for example, that the next nominee were a genuinely distinguished moderate, with unpredictable views on currently controversial issues. Assume also that the selection of such a nominee emerged through a process in which the Senate offered its advice and threatened to refuse its consent. If a Republican President nominated some such person, the dynamics of political compromise ought to leave him freer to fill the next seat with a genuinely distinguished conservative. Over the course of time, a President who, facing an independent Senate, was prepared to compromise on likely voting patterns for genuine distinction, might well, and certainly should, find a Senate prepared to do the same. Both distinction and diversity-in the sense of maintaining a Court that reflected, in an appropriate way, the heterogeneity of public opinion-might be furthered in this way.

It is naive to suppose that this would be the inevitable result of the independent Senate role we describe. But there is reason to believe that these desirable outcomes are more likely if the Senate takes an independent approach. The Supreme Court appointment process is already politicized; the institutions established by the executive branch for screening prospective nominees attest to how deep-seated that politicization is. Allowing the Senate to meet the Administration openly on grounds of a nominee's likely voting patterns holds out some hope of reducing the politicization. And even if it does not do that, it will nonetheless break the unjustified monopoly that the Administration now has on the consideration of political orientation in nominees. Above all, an active Senate role might increase the likelihood of a distinguished Supreme

104. The point raises an important and controversial question: Should Senators be allowed to question the nominee about votes in specific cases? In brief, we advocate the following approach. Members of the Senate are fully entitled to ask such specific questions as they like. Nominees are entitled to refuse to answer-if they do refuse, they may do so in part on the plausible ground that no assurances should be given in advance, lest judicial independence be compromised. But for its part, the Senate is entitled to take into account the refusal to answer-subject to the important qualifications we discuss below. See infra Part III.C. Senators may conclude that the absence of relevant assurances counts against confirmation. 
Court, one whose members offer the appropriate qualities of character, excellence, and diversity of view.

\section{The Problem of "Campaigning" for the Court}

No one would welcome an appointments process in which nominees to the Court made campaign promises-commitments about how they will vote on particular issues-to various Senators in the hope of gaining enough votes to be confirmed. Of course, once a nominee is confirmed, any such commitment is unenforceable. But a nominee who promised during a Senate hearing that she would not, for example, vote to overrule Roe $v$. Wade ${ }^{105}$ would inevitably think twice about the public uproar that would result if she were persuaded by contrary arguments as a Justice and reneged on that promise.

At first glance our proposal seems likely to encourage such campaign promises. On balance, however, it is unlikely that Senate independence would make this problem worse than it already is. In fact, it might improve matters.

Whenever politics becomes strongly ideological, people who want to be on the Supreme Court have an incentive to campaign for the Court by reshaping their views. When a President pursues an ideological appointments strategy, the incentive is even greater. It is a safe prediction, for example, that the Bush Administration will not appoint anyone who has taken an unequivocal position in support of Roe. ${ }^{106}$ Neither the President nor his advisers would have to ask a prospective nominee overt questions about such issues as abortion, affirmative action, or capital punishment. Since the President has the whole country to choose from, he can select someone who is reliable on these issues. People who want to be on the Court know that.

If the Senate were to begin to act in the independent way we describe, what would change is not the degree of this kind of campaigning, but only the target. One could expect some people who see themselves as potential nominees to begin tailoring their public views to conform more closely to those of key Senators, instead of trying to attract the attention of the Administration as they do now. This would not be a desirable state of affairs, but it is no worse than what we have now. Moreover, campaigning of this kind, which often consists of writing editorials and making speeches, is not nearly as troublesome as explicit commitments made to a Senator in public hearings.

Perhaps surprisingly, our proposal should have the effect of reducing the likelihood of that kind of public commitment. Senators are aware of the unseemliness of a Supreme Court nominee having to campaign for office. Senators on the Judiciary Committee, for example, often try to learn about the nominee's

105. 410 U.S. 113 (1973).

106. The point is not partisan: the Roosevelt Administration would not have appointed anyone who stated that the New Deal was unconstitutional, and a Democratic President in the near future is unlikely to appoint anyone who unequivocally opposes Roe. 
views while taking pains not to ask for commitments on specific issues. Moreover, Senators realize that public questioning of a well-coached nominee, by Senators who must be careful not to look too partisan or too bullying, is a particularly ineffective way to find out what a nominee really thinks.

What forces the Senators to ask uncomfortably specific questions is their sense that they would otherwise be excluded from any effective role in shaping the Court's orientation. If the Senate asserted itself more fully-if it were a partner in choosing the nominee, instead of an after-the-fact check on acceptability-it would not need to rely so heavily on the crude and ineffective tool of public questioning. As matters now stand, the President has an incentive to choose the most conservative nominee he can find and then devise the best way to slide that nominee through the Senate. The nominee then says what she must in the confirmation hearings. If the Senate were a full partner in the appointments process, the President would have a greater incentive to obtain the assent of key Senators before announcing a nominee. Those Senators, in deciding whether to assent, could examine the candidate's entire record-just as the President can. Like the President, they would not need to seek explicit commitments on specific issues at the time of the nomination. Indeed, they would be foolish to rely on such a "campaign promise" unless the nominee's entire record made it credible.

The current system creates a substantial incentive to make public commitments; unless a nominee can satisfy the Senate that she is acceptable, the Senate will reject the nomination even now. Thus, nominees routinely genuflect to Brown and, now, Griswold. There is good reason to believe that the changes in the Senate's approach that we propose will not make matters any worse, and may even make them better.

\section{Improving the Process}

As our previous arguments suggest, an independent Senate role might, perhaps paradoxically, diminish the importance of the confirmation hearings. Currently, the confirmation hearing is a climactic media spectacle that determines whether the President can slip his nominee (whom everyone knows was chosen in part for her likely voting patterns, despite the President's claims that merit was the exclusive basis) past the Senate (which is also concerned with the nominee's likely votes, notwithstanding the Senators' contention that they are concerned only with character, competence, and whether the nominee is in the "mainstream"). The fate of legislation is not decided in this manner. For the reasons outlined above, judicial appointments would not be decided in this way either, if the Senate approached them with the same independence it brings to the President's legislative initiatives.

In any event, many of the problems of the current appointments process, particularly those pointed out by supporters of the Administration, arise from 
the central role of the confirmation hearing. Whether or not the Senate adopts a more independent view of its role (and perhaps especially if it does), a number of steps might be taken to reduce the significance of the hearing and to improve the process in general.

(1) The President should seek and take seriously the "advice" offered by the Senate. We have suggested several ways in which this might be done: the President might solicit a list of the Senate's preferred candidates; key Senators might be invited to review and comment on possible choices; or there might be ongoing discussions between Senators and the White House about possible nominees. If such consultations produced a mutually agreeable candidate, the hearings would be simpler and much less contentious. Even if the President could not agree with key Senators on a nominee, serious consultation would reduce the range of disagreement and, therefore, the adversarial nature of the hearings. The hearings would cease to be the only forum in which the Senate could make its voice heard.

(2) More generally, it is in the Senate's own interest to place less weight on the confirmation hearings. Both sides have pointed to serious problems in the current emphasis on those hearings. ${ }^{107}$ Of particular importance is the threat to judicial independence posed by ongoing conversations between the Department of Justice and the White House on the one hand, and the nominee on the other. These conversations frequently involve matters likely to reach the Court. It is unfortunate if the nominee has been schooled in the views of the current Administration. Moreover, the hearings sometimes become mired in irrelevant or misleading factors, such as the nominee's telegenic qualities and how the various Senators "look." Televised competition between Senators and the nominee, or among the Senators, is hardly in the national interest. Finally, because of their immediacy and drama, the hearings tend to assume disproportionate importance. They can dwarf the much more relevant information provided by the pre-nomination record. The pre-nomination record is a far more reliable indicator of the nominee's views. The Senate should rely principally on that record, rather than a nominee's testimony, in deciding whether to consent to the nomination. Such an emphasis would reduce many of the problems of the current system.

This is not to say that hearings do not have some virtues. At least in their ideal form, they have an important educative function. Confirmation hearings might help inform the public of the actual and potential role of the Supreme Court, allowing diverse views to be expressed on that subject. Too often the

107. See supra notes $1-4$ and accompanying text. We note in particular the distortions of the prenomination record of Judge Robert Bork, catalogued in ROBERT H. BORK, THE TEMPTING OF AMERICA: THE POLITICAL SEDUCTION OF THE LAW 323-36 (1988); the extensive preparation of nominees David Souter and Clarence Thomas before their hearings; the reliance on general appearance before the camera in the Bork, Souter, and Thomas hearings; the effects of television coverage on some Senators' behavior, and the uninformative generalities provided by several recent nominees in their statements to the Senators. 
nature of the Court, and of constitutional law generally, is unnecessarily obscured; hearings can serve to enlighten. But the current system offers only minor advances in public education, and it does so while introducing a range of distortions into the process. Moreover, it appears that the hearings can be truly educative only on those occasions when the system is, in a sense, out of equilibrium. This occurs, for example, when the questioners unexpectedly change their tactics and the Administration and nominee are caught unprepared. Once the executive adjusts, the hearings become stylized and their educative value is reduced. Reducing the centrality of the hearings would significantly advance the goal of a healthy confirmation process. ${ }^{108}$

(3) The Senate should place the burden of proof-with respect to character, excellence, and point of view- on the nominee. No one has a right to sit on the Supreme Court. The country need not accept nominees simply because they might ultimately prove distinguished or open-minded. A "hope" to this effect is insufficient. ${ }^{109}$ In exercising its consent power, the Senate is entitled to reject nominees simply because they have not established that they have the requisite qualities, even if there is considerable uncertainty on that point.

This understanding of the burden of proof would remove some of the difficulties introduced by greater reliance on the pre-nomination record. For example, such reliance creates an incentive for the President to nominate people without extensive records, simply because they have not said anything controversial. ${ }^{110}$ The Senate need not confirm someone of this sort. Indeed, it should presume that a candidate of this kind will not meet the burden of proof.

(4) The Senate might rely more formally on lawyers familiar with the workings and practices of the Court. The Senators have an extraordinary range of duties. Although many Senators are, by training and temperament, well equipped to handle constitutional issues, it is unreasonable to expect members of the Judiciary Committee to be specialists in the intricacies of legal doctrine. Perhaps some of the questioning should be done directly by outside counsel. Perhaps there should be sharp time limits on senatorial questioning. In any case, the difficulties inherent in the hearing process, especially in an era dominated

108. A reduced emphasis on the hearings might, however, also work against an independent senatorial role, at least to the extent that such hearings mobilize public opposition to a nominee. We hope that such a role does not depend on such mobilization, produced as it sometimes is by arbitrary or irrelevant factors.

109. It follows that the burden of proof required in a criminal trial is inappropriate in the confirmation hearings. A heavy burden of proof is correctly placed on governmental efforts to incarcerate someone, or to convict him of a criminal offense; in view of the enormous harm of a mistake-the conviction of an innocent person-the state must bear an extraordinary burden. In a confirmation hearing, the possibility of harm argues in precisely the opposite direction. Someone wrongly denied a seat on the Court may be embarrassed or worse, but is hardly placed in the position of a convicted criminal. Someone wrongly placed on the Court is in a unique position to commit social harm. For this reason we think much of the "heavy burden of proof" rhetoric in the confirmation hearings involving Justice Thomas was misconceived-though we do not confront the many complexities of those hearings, unfortunate by any standard, in this space.

110. As argued at the time by Bork's supporters, an unfortunate consequence of the Bork hearings has been precisely this. 
by television coverage, argue strongly against the current emphasis on a process that has become a public spectacle.

These are simply a few suggestions intended to counteract some of the difficulties likely to accompany an independent role for the Senate. Other solutions are surely possible as well. The principal point is that the confirmation hearing ought not to be the centerpiece of the decision whether or not to consent to a judicial appointment. There are far more reliable and desirable means from which the Senate can draw information about the candidate.

\section{CONCLUSION}

The Constitution contemplates an important role for the Senate in the confirmation process. It provides that there will be senatorial "advice" before the fact. It ensures that no nominee may serve without senatorial "consent." There is especially strong structural support for such a role in connection with appointments to the branch of government that resolves disputes and allocates power between the other two branches.

We are in the midst of an extraordinary period-one in which Republican Presidents have made eleven consecutive appointments, usually with ideological motivations, even though the Congress was solidly controlled by the Democratic Party for virtually this entire period. In this context, it is unhealthy for the Senate to maintain a posture of deference. The current system, unprecedented in the nation's history, creates serious risks from the standpoint of checks and balances. The Senate should now assume a self-consciously independent role. It should insist on its constitutional prerogatives. 


\section{APPENDIX}

TABLE 1. Judicial Appointments by President

\begin{tabular}{|c|c|c|c|c|c|}
\hline YEAR & PRESIDENT & $\begin{array}{l}\text { PRESIDENT'S } \\
\text { PARTY }^{\mathrm{a}}\end{array}$ & $\begin{array}{l}\text { JUSTICE(S) } \\
\text { APPONTED }\end{array}$ & $\begin{array}{c}\text { YEAR } \\
\text { CONFIRMED }\end{array}$ & $\begin{array}{l}\text { SENATE'S } \\
\text { PAFTY }^{\mathrm{a}}\end{array}$ \\
\hline \multirow[t]{10}{*}{1789} & Washington (10) & $\mathbf{F}$ & John Jay CJ & 1789 & Ad \\
\hline & & & John Rutledge & 1789 & Ad \\
\hline & & & William Cushing & 1789 & Ad \\
\hline & & & James Wilson & 1789 & Ad \\
\hline & & & John Blair & 1789 & Ad \\
\hline & & & James Iredell & 1790 & Ad \\
\hline & & & Thomas Johnson & 1791 & $\mathbf{F}$ \\
\hline & & & William Paterson & 1793 & F \\
\hline & & & Samuel Chase & 1796 & $\mathbf{F}$ \\
\hline & & & Oliver Elsworth $\mathrm{CJ}$ & 1796 & $\mathbf{F}$ \\
\hline \multirow[t]{3}{*}{1797} & J. Adams (3) & F & Bushrod Washington & 1798 & $\mathbf{F}$ \\
\hline & & & Alfred Moore & 1799 & $\mathbf{F}$ \\
\hline & & & John Marshall CJ & 1801 & $\mathbf{F}$ \\
\hline \multirow[t]{3}{*}{1801} & Jefferson (3) & $\mathrm{DR}$ & William Johnson & 1804 & $\mathrm{DR}$ \\
\hline & & & H. Brockholst Livingston & 1806 & $\mathrm{DR}$ \\
\hline & & & Thomas Todd & 1807 & DR \\
\hline \multirow[t]{2}{*}{1809} & Madison (2) & $\mathbf{D R}$ & Joseph Story & 1811 & $\mathrm{DR}$ \\
\hline & & & Gabriel Duvall & 1811 & DR \\
\hline 1817 & Monroe (1) & $\mathrm{DR}$ & Smith Thompson & 1823 & DR \\
\hline 1825 & J.Q. Adams (1) & C & Robert Trimble & 1826 & Ad \\
\hline \multirow[t]{6}{*}{1829} & Jackson (G) & D & John McLean & 1829 & $\mathrm{D}$ \\
\hline & & & Henry Baldwin & 1830 & $D$ \\
\hline & & & James M. Wayne & 1835 & D \\
\hline & & & Roger B. Taney CJ & 1836 & $\mathrm{D}$ \\
\hline & & & Philip B. Barbour & 1836 & $\mathrm{D}$ \\
\hline & & & John Catron & 1837 & D \\
\hline \multirow[t]{2}{*}{1837} & Van Buren (2) & $D$ & John MaKinley & 1837 & $\mathbf{D}$ \\
\hline & & & Peter V. Daniel & 1841 & $\mathrm{D}$ \\
\hline 1841 & W. Harison (0) & $\mathrm{W}$ & & & \\
\hline 1841 & Tyler (1) & $W$ & Samuel Nelson & 1845 & $\mathrm{~W}$ \\
\hline \multirow[t]{2}{*}{1845} & Polk (2) & D & Levi Woodbury & 1845 & $\mathrm{D}$ \\
\hline & & & Robert C. Grier & 1846 & $\mathrm{D}$ \\
\hline 1849 & Taylor (0) & $\mathbf{W}$ & & & \\
\hline 1850 & Fillmore (1) & $\mathbf{W}$ & Benjamin R. Curtis & 1851 & D \\
\hline 1853 & Pierce (1) & D & John A. Campbell & 1853 & D \\
\hline
\end{tabular}

${ }^{a}$ Letter symbols for political parties: Ad - Administration; C - Coalition; D - Democratic; DR - Democratic-Republican; F - Federalist; R - Republican; W - Whig. 


\begin{tabular}{|c|c|c|c|c|}
\hline 1857 & Buchanan (1) & D & Nathan Clifford & 1858 \\
\hline \multirow[t]{5}{*}{1861} & Lincoln (5) & $\mathbf{R}$ & Noah H. Swayne & 1862 \\
\hline & & & Samuel F. Miller & 1862 \\
\hline & & & David Davis & 1862 \\
\hline & & & Stephen J. Field & 1863 \\
\hline & & & Salmon P. Chase CJ & 1864 \\
\hline 1865 & A. Johnson (0) & $\mathbf{R}$ & & \\
\hline \multirow[t]{4}{*}{1869} & Grant (4) & $\mathbf{R}$ & William Strong & 1870 \\
\hline & & & Joseph P. Bradley & 1870 \\
\hline & & & Ward Hunt & 1872 \\
\hline & & & Morrison R. Waite CJ & 1874 \\
\hline \multirow[t]{2}{*}{1877} & Hayes (2) & $\mathbf{R}$ & John M. Harlan & 1877 \\
\hline & & & William B. Woods & 1880 \\
\hline 1881 & Garfield (1) & $\mathbf{R}$ & Stanley Matthews & 1881 \\
\hline \multirow[t]{2}{*}{1881} & Arthur (2) & $\mathbf{R}$ & Horace Gray & 1881 \\
\hline & & & Samuel Blatchford & 1882 \\
\hline \multirow[t]{2}{*}{1885} & Cleveland (2) & D & Lucius Q.C. Lamar & 1888 \\
\hline & & & Melville W. Fuller CJ & 1888 \\
\hline \multirow[t]{4}{*}{1889} & B. Harrison (4) & $\mathbf{R}$ & David J. Brewer & 1889 \\
\hline & & & Henry B. Brown & 1890 \\
\hline & & & George Shiras, Jr. & 1892 \\
\hline & & & Howell E. Jackson & 1893 \\
\hline \multirow[t]{2}{*}{1893} & Cleveland (2) & $\mathrm{D}$ & Edward D. White & 1894 \\
\hline & & & Rufus W. Peckham & 1895 \\
\hline 1897 & McKinley (1) & $\mathbf{R}$ & Joseph McKerna & 1898 \\
\hline \multirow[t]{3}{*}{1901} & T. Roosevelt (3) & $\mathbf{R}$ & Oliver W. Holms, Jr. & 1902 \\
\hline & & & William R. Day & 1903 \\
\hline & & & William H. Mocdy & 1906 \\
\hline \multirow[t]{6}{*}{1909} & Taft (6) & $\mathbf{R}$ & Horace H. Lurton & 1909 \\
\hline & & & Charles E. Hughes & 1910 \\
\hline & & & Edward D. White $C^{C}$ & 1910 \\
\hline & & & Willis Van Devanter & 1910 \\
\hline & & & Joseph R. Lamar & 1910 \\
\hline & & & Mahlon Pitney & 1912 \\
\hline \multirow[t]{3}{*}{1913} & Wilson (3) & $D$ & James C. McRejnolds & 1914 \\
\hline & & & Louis D. Brandeis & 1916 \\
\hline & & & John H. Clarke & 1916 \\
\hline
\end{tabular}




\begin{tabular}{|c|c|c|c|c|c|}
\hline \multirow[t]{4}{*}{1921} & \multirow[t]{4}{*}{ Harding (4) } & \multirow[t]{4}{*}{$\mathbf{R}$} & William H. Taft CJ & 1921 & $R^{d}$ \\
\hline & & & George Sutherland & 1922 & $\mathbf{R}$ \\
\hline & & & Pierce Butler & 1922 & $\mathbf{R}$ \\
\hline & & & Edward T. Sanford & 1923 & $\mathbf{R}$ \\
\hline 1923 & Coolidge (1) & $\mathbf{R}$ & Harlan F. Stone & 1925 & $\mathbf{R}$ \\
\hline \multirow[t]{3}{*}{1929} & \multirow[t]{3}{*}{ Hoover (3) } & \multirow[t]{3}{*}{$\mathbf{R}$} & Charles E. Hughes CJ & 1930 & $\mathbf{R}$ \\
\hline & & & Owen J. Roberts & 1930 & $\mathbf{R}$ \\
\hline & & & Benjamin N. Cardozo & 1932 & $\mathbf{R}$ \\
\hline \multirow[t]{9}{*}{1933} & \multirow[t]{9}{*}{ Roosevelt (9) } & \multirow[t]{9}{*}{$\mathbf{D}$} & Hugo L. Black & 1937 & $\mathbf{D}$ \\
\hline & & & Stanley R. Reed & 1938 & D \\
\hline & & & Felix Frankfurter & 1939 & $\mathbf{D}$ \\
\hline & & & William O. Douglas & 1939 & D \\
\hline & & & Frank Murphy & 1940 & D \\
\hline & & & Harlan F. Stone CJe & 1941 & $\mathbf{D}$ \\
\hline & & & James F. Bymes & 1941 & $\mathbf{D}$ \\
\hline & & & Robert H. Jackson & 1941 & $\mathbf{D}$ \\
\hline & & & Wiley B. Rutledge & 1943 & D \\
\hline \multirow[t]{4}{*}{1945} & \multirow[t]{4}{*}{ Truman (4) } & \multirow[t]{4}{*}{ D } & Harold H. Burton & 1945 & $\mathbf{D}$ \\
\hline & & & Fred $M$. Vinson CJ & 1946 & $\mathbf{D}$ \\
\hline & & & Tom C. Clark & 1949 & $\mathbf{D}$ \\
\hline & & & Sherman Minton & 1949 & $\mathbf{D}$ \\
\hline \multirow[t]{5}{*}{1953} & \multirow[t]{5}{*}{ Eisenhower (5) } & \multirow[t]{5}{*}{$\mathbf{R}$} & Earl Warren CJ & 1953 & $R^{\mathbf{f}}$ \\
\hline & & & John M. Harlan & 1955 & $\mathrm{D}^{\mathrm{g}}$ \\
\hline & & & William J. Brennan, Jr. & 1957 & D \\
\hline & & & Charles E Whittaker & 1957 & $D^{h}$ \\
\hline & & & Potter Stewart & 1959 & D \\
\hline \multirow[t]{2}{*}{1961} & \multirow[t]{2}{*}{ Kennedy (2) } & \multirow[t]{2}{*}{ D } & Byron R. White & 1962 & $\mathbf{D}$ \\
\hline & & & Arthur J. Goldberg & 1962 & D \\
\hline \multirow[t]{2}{*}{1963} & \multirow[t]{2}{*}{ Johnson (2) } & \multirow[t]{2}{*}{ D } & Abe Fortas & 1965 & $\mathbf{D}$ \\
\hline & & & Thurgood Marshall & 1967 & D \\
\hline \multirow[t]{4}{*}{1969} & \multirow[t]{4}{*}{ Nixon (4) } & \multirow[t]{4}{*}{$\mathbf{R}$} & Warren E. Burger CJ & 1969 & $\mathbf{D}$ \\
\hline & & & Hanry A. Blackmun & 1970 & D \\
\hline & & & Lewis F. Powell & 1971 & D \\
\hline & & & William H. Rehnquist & 1971 & $\mathbf{D}$ \\
\hline 1974 & Ford (1) & $\mathbf{R}$ & John Paul Stevens & 1975 & $\mathbf{D}$ \\
\hline 1977 & Carter (0) & D & & & \\
\hline \multirow[t]{4}{*}{1981} & \multirow[t]{4}{*}{ Reagan (4) } & $\mathbf{R}$ & Sandra Day O'Connor & 1981 & $\mathbf{R}$ \\
\hline & & & William H. Rehnquist $\mathrm{CJ}^{\mathrm{e}}$ & 1986 & $\mathbf{R}$ \\
\hline & & & Antonin Scalia & 1986 & $\mathbf{R}$ \\
\hline & & & Anthony M. Kennedy & 1987 & D \\
\hline
\end{tabular}

d The Republican Party held the Senate'by a two-vote margin in the 66th Congress.

c Denotes a Chief Justice who was elevated from the position of Associate Justice.

The Republican Party held the Senate in the 83d Congress by only one vote, with one Senator affiliating with neither the Democratic nor the Republican Party.

g In the 84th Congress, the Democrats held the Senate by only one vote, with one Senator affiliaing with neither the Republican nor the Democratic Party.

$h$ The Democrats' majority in the Senate in the 85 th Congress was only two votes.
Thor the Democratic Party. 
[Vol. 101: 1491

$1989 \quad$ Bush (2)

R David H. Souter

1990

1991

D

Clarence Thomas

D

TABLE 2. Appointments and Senate Majority Party

\begin{tabular}{|c|c|c|c|c|c|}
\hline \multirow[b]{2}{*}{ YEAR } & \multirow[b]{2}{*}{ PRESIDENT(S) } & \multirow[b]{2}{*}{ PARTY } & \multirow{2}{*}{$\begin{array}{l}\text { NURIBER OF } \\
\text { JUSTICES } \\
\text { APFOINTED }\end{array}$} & \multicolumn{2}{|c|}{ SENATE MIAJORTY PARTI } \\
\hline & & & & D & $\mathbf{R}$ \\
\hline $1921-33$ & Harding/Coolidge/Hoover & $\mathbf{R}$ & 8 & 0 & 8 \\
\hline 1953-61 & Eisenhower & $\mathbf{R}$ & 5 & 4 & 1 \\
\hline $1969-92$ & Nixon/Ford/Reagan/Bush & $\mathbf{R}$ & 11 & 8 & 3 \\
\hline $1933-53$ & Roosevelt/Truman & D & 13 & 13 & 0 \\
\hline 1961-69 & Kennedy/Johnson & $\mathbf{D}$ & 4 & 4 & 0 \\
\hline 1979-81 & Carter & D & 0 & & \\
\hline
\end{tabular}

HAROLD W. STANLEY \& RICHARD E. NIEM, VTTAL STATISTICS ON AMERICAN POLIMCS 292-97 (1992); EIDER WITT, GUIDE TO THE U.S. SUPREME COURT 995-98 (1990).

i This includes three elevations from Associate Justice to Chief Justice, two in the Harding/Coolidge/Hoover era, and one in the Nixon/Ford/Reagan/Bush era. 